\title{
SIMULASI PEMBUATAN DAN PENGGUNAAN MEDIA PEMBELAJARAN BIOLOGI DI SMA NEGERI 1 KAMBERA
}

\author{
Yohana Makaborang1), Erfy Melany Lalupanda'), Vidriana Oktoviana Bano1), \\ Ospensius Kawawu Taranau1), Riwa Rambu Hada Endah'1), Yohana Njdoeroemana1)
}

1)Pendidikan Biologi, Fakultas Ilmu-IImu Sosial, Universitas Kristen Wira Wacana Sumba, Nusa Tenggara Timur,
Indonesia

Corresponding author : Yohana Makaborang

E-mail : yohanamakaborang@unkriswina.ac.id

\begin{abstract}
ABSTRAK
Tujuan dilaksanakan pengabdian kepada masyarakat ini adalah untuk memberikan simulasi kepada Guru Biologi di SMA Negeri 1 Kambera tentang cara pembuatan dan penggunaan media pembelajaran Biologi dalam proses pembelajaran. Pengabdian ini menggunakan metode ceramah, diskusi, tanya jawab, studi kasus, curah pendapat, simulasi dan praktik. Hasil dari kegiatan pengabdian ini adalah guru Biologi mampu membuat dan menggunakan media pembelajaran. Kegiatan ini mampu meningkatkan antusias dan motivasi guru dalam memanfaatkan media pembelajaran. Selain itu juga guru-guru dapat memperoleh pengetahuan mengenai pembuatan media pembelajaran dalam bentuk Tiga Dimensi dan produk ini dapat digunakan dalam pembelajaran di kelas.
\end{abstract}

Kata kunci: media pembelajaran; biologi; tiga dimensi

\begin{abstract}
The aims of this community service is to provide a simulation to the Biology teacher at SMA Negeri 1 Kambera on how to make and use Biology learning media in the learning process. This service uses lectures, discussions, question and answer methods, case studies, brainstorming, simulations and practices. The result of this service activity is that the Biology teacher is able to create and use learning media. This activity is able to increase the enthusiasm and motivation of teachers in utilizing learning media. In addition, teachers can also gain knowledge about making learning media in the form of three dimensions and this product can be used in classroom learning.
\end{abstract}

Keywords: learning media; biology; three dimensions

\section{PENDAHULUAN}

Pengabdian kepada masyarakat merupakan suatu kegiatan yang bertujuan untuk menjawab kebutuhan masyarakat. Dengan melakukan kegiatan ini diharapkan dapat membantu masyarakat supaya masyarakat di bekali dengan pengetahuanpengetahuan tentang pemanfaatan pengembangan ilmu pengetahuan. Salah satu pengetahuan yang bermanfaat untuk masyarakat, khususnya guru adalah terkait media pembelajaran.

Media pembelajaran merupakan alat yang dapat digunakan di dalam maupun di luar kelas. Media pembelajaran digunakan sebagai alat bantu untuk menghubungkan antara guru, materi dan siswa dalam proses interaksi belajar mengajar (Nurmadiah, 2016). Sejalan dengan pernyataan tersebut Soimah (2018) menyatakan bahwa penggunaan media pengajaran dalam proses belajar mengajar dapat membangkitkan rasa ingin tahu dan motivasi belajar siswa.

Pengaplikasian media dalam pembelajaan juga dapat membatu para guru- guru untuk mengajar anak didik tidak hanya berdasarkan teori tetapi juga menggunakan media pembelajaaran secara langsung, sehingga anak didik memahami teori-teori yang disampaikan.

Kami menyadari bahwa tingkat pertumbuhan pendidikan di desa dewasa ini tidak bertumbuh secara signifikan dibandingkan dengan tingkat pertumbuhan pendidikan yang ada di kota. Oleh karena itu kami tergerak untuk membantu guru-guru mensimulasikan pembuatan media pembelajaran sehingga siswa dapat memahami teori-teori pembelajaran secara nyata dan mempermudahkan proses belajar mengajar dalam kelas. Dengan pengaplikasian metode seperti ini dapat membuat tingkat pertumbuhan pendidikan di desa lebih maju dari sebelumnya.

Hal ini kami lakukan karena kami merasa bertanggung jawab untuk memperhatikan lingkungan sosial supaya dapat bertumbuh sebagaimana seharusnya. Peran ini kami ambil karena kami ingin berpartisipasi dengan pemerintah dalam hal membangun tingkat pendidikan yang layak di desa 
Program Studi Pendidikan Biologi Universitas Kristen Wira Wacana Sumba melalui mata kuliah Media Pembelajaran Biologi telah menghasilkan produk berupa media pembelajaran yang dapat menunjang pembelajaran biologi di tingkat SMA. Dengan produk yang dihasilkan tersebut dapat dimanfaatkan untuk melakukan kegiatan pengabdiaan kepada masyarakat di tingkat SMA. Produk ini juga dapat memberikan pemahaman dan pengetahuan kepada guruguru dalam hal pembuatan dan pemanfaatan media pembelajaran biologi.

Biologi merupakan ilmu sains yang memiliki cakupan materi yang luas dan kompleks (Tammu, 2018). Untuk mencapai tujuan pembelajaran Biologi, dibutuhkan media. Pemilihan media pembelajaran harus disesuaikan dengan materi, strategi maupun metode yang digunakan.

Berdasarkan paparan tersebut maka media pembelajaran menduduki peran yang sangat penting dalam pembelajaran. Sehingga seorang guru Biologi diharapkan harus mampu membuat dan menggunakan media dalam pembelajaran.

$$
\text { Adapun tujuan dilaksanakan }
$$

pengabdian kepada masyarakat ini adalah untuk memberikan simulasi kepada Guru Biologi di SMA Negeri 1 Kambera tentang cara pembuatan dan penggunaan media pembelajaran Biologi dalam proses pembelajaran.

\section{METODE PENELITIAN}

Kegiatan pengabdian kepada masyarakat dilakukan di SMA Negeri 1 Kambera dan di peruntukkan bagi guru-guru mata pelajaran Biologi. Waktu pelaksanaan kegiatan pengabdian dimulai tanggal 08 Februari - 09 Maret 2019 atau (66 Jam). Peserta yang terlibat dari sekolah mitra yaitu SMAN 1 Kambera sebanyak 3 orang. Metode penelitian yang digunakan dalam pengabdian yaitu metode ceramah, diskusi, tanya jawab, curah pendapat, studi kasus, curah pendapat, simulasi dan praktik (Putri Purwaningrum \& Ahyani, 2020). Adapun tahapan kegiatan sebagai berikut:

1. Tahapan Perencanaan

Pada tahap ini melakukan studi pendahuluan yaitu studi lapangan dan menganalisis kebutuhan sekolah sesuai dengan kenyataan atau fakta di lapangan untuk menentukan solusi dalam permasalahan yang ditemukan. Pengumpulan studi literatur dan sumber rujukan. Pembuatan perijinan kepada sekolah mitra (SMA Negeri 1 Kambera) dengan perjanjian dan kesempakatan kerja sama dalam pelaksanaan kegiatan.

2. Tahap Persiapan

Pada tahap ini dilakukan persiapan tempat dalam hal ini ruangan yang di gunakan dalam simulasi, menyiapkan alat dan bahan simulasi dan menyiapkan materi pelatihan simulasi media pembelajaran.

3. Tahap Pelaksanaan

Pada Tahap ini ketua PKM mempresentasikan materi simulasi pembuatan media pembelajaran dalam dalam bentuk 3 Dimensi pada mata pelajaran biologi. Adapun tahapan-tahapan yang dilakukan adalah Tahap Follow Up, pada tahap ini tim pengabdian mendampingi guru-guru dalam kegiatan praktik dalam membuat media pembelajaran Biologi dalam bentuk 3 Dimensi.

Tahap simulasi dan praktik pada tahap ini tim pengabdian dalam hal ini dosen dan mahasiswa membantu guru-guru atau peserta pelatihan melakukan simulasi pembuatan media pembelajaran dalam bentuk 3 Dimensi pada mata pelajaran biologi.

Tahap Evaluasi, pada tahap ini tim pengabdian dosen dan mahasiswa serta guru-guru biologi melakukan kegiatan evaluasi dalam bentuk saling menilai terhadap hasil karya atau produk dan kegiatan pelatihan serta praktek dalam simulasi pembuatan media pembelajaran dalam bentuk 3 Dimensi pada mata pelajaran Biologi. Tim Pengabdian berperan dalam memberikan masukan , saran, dan peghargaan terkait hasil pengabdian produk media pembelajaran, simulasi, dan kegiatan praktek pembuatan media pembelajaran dalam bentuk 3 Dimensi mata pelajaran biologi.

\section{HASIL DAN PEMBAHASAN}

Kegiatan Pengabdian kepada
Masyarakat tentang simulasi media pembelajaran Biologi di SMA Negeri 1 Kambera, Kabupaten Sumba Timur di ikuti oleh guru Biologi. Guru mata pelajaran Biologi perlu memiliki keterampilan dalam pembuatan dan penggunaan media pembelajaran untuk dapat mencapai tujuan pembelajaran.

Tahapan kegiatan pengabdian ini ada beberapa tahapan yaitu tahap Perencanaan Kegiatan; tahap Persiapan Kegiatan; tahap Pelaksanaan Kegiatan meliputi tahap Follow Up Kegiatan, tahap Simulasi Praktik Kegiatan; dan tahap Evaluasi Kegiatan. 
Tahapan perencanaan kegiatan dilakukan perwakilan dari tim pengabdian melakukan studi pendahuluan dengan cara wawancara dengan guru dan kepala sekolah di SMAN 1 Kambera. Hasil wawancara tersebut diperoleh bahwa guru-guru biologi membutuhkan bantuan dalam hal pembuatan media pembelajaran dalam bentuk 3 dimensi untuk digunakan dalam pembelajaran di kelas. Oleh karena itu tim pengabdian berencana untuk dilakukan pelatihan cara pembuatan media pembalajaran dalam bentuk 3 dimensi. Dokumentasi kegiatan ini dapat terlihat pada Gambar 1.

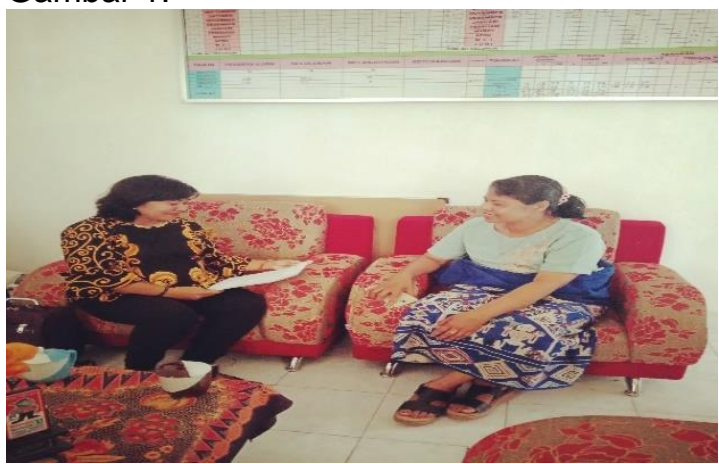

Gambar 1. Tahapan Perencanaan Kegiatan

Tahapan persiapan dilakukan dosen menyiapkan bahan pelatihan dan pembuatan tentang manfaat, jenis dan pentingnya penggunaan media dalam proses pembelajaran Biologi. Selanjutnya Tim pengabdian mempersiapkan ruangan tempat pelatihan dan berbagai contoh media pembelajaran dalam bentuk 3 dimensi. Dokumentasi kegiatan ini dapat terlihat pada gambar 2.

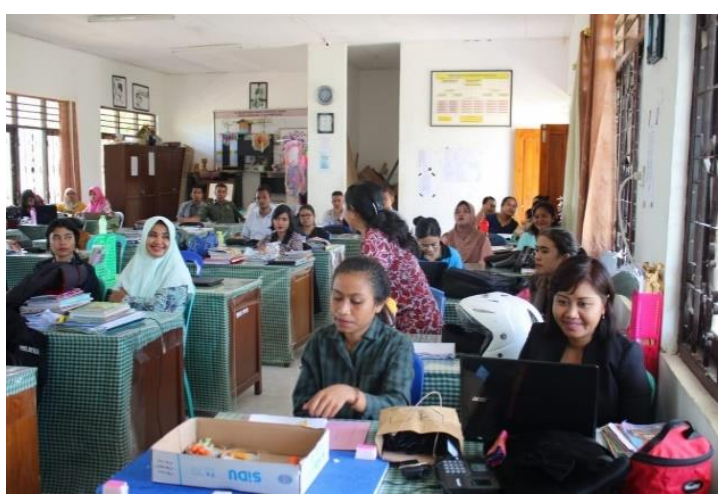

Gambar 2. Tahapan Persiapan Kegiatan

Selanjutnya, tahapan pelaksanaan kegiatan, pada tahapan ini dilakukan dengan tahap follow up simulasi praktik dan evaluasi. Sebelum dilakukan pendampingan dan praktik serta evaluasi kegiatan dosen mempresentasikan materi tentang manfaat, jenis dan pentingnya penggunaan media dalam proses pembelajaran Biologi. Dokumentasi kegiatan ini dapat terlihat pada gambar 3 .

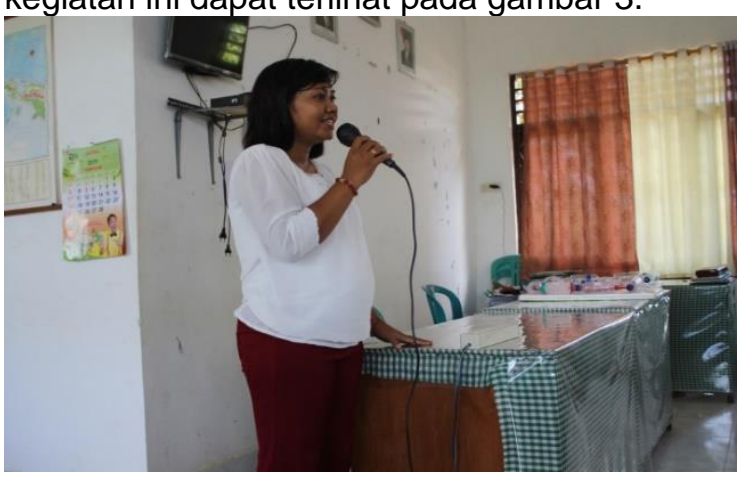

Gambar 3. Tahapan Pelaksanaan

Penyampaian Materi Kegiatan.

Selanjutnya, dosen, Bersama mahasiswa melakukan pendampingan kepada guru-guru serta bersama-sama mempraktekkan cara pembuatan beberapa media pembelajaran Biologi diantaranya media $3 \mathrm{D}$ virus Bakteriofag, kultur jaringan wortel, sel hewan dan sel tumbuhan, media contoh (sistem pernapasan, sistem ekskresi, sistem peredaran darah). Dokumentasi kegiatan ini dapat dilihat pada gambar 4, 5, 6, 7, 8 dan 9

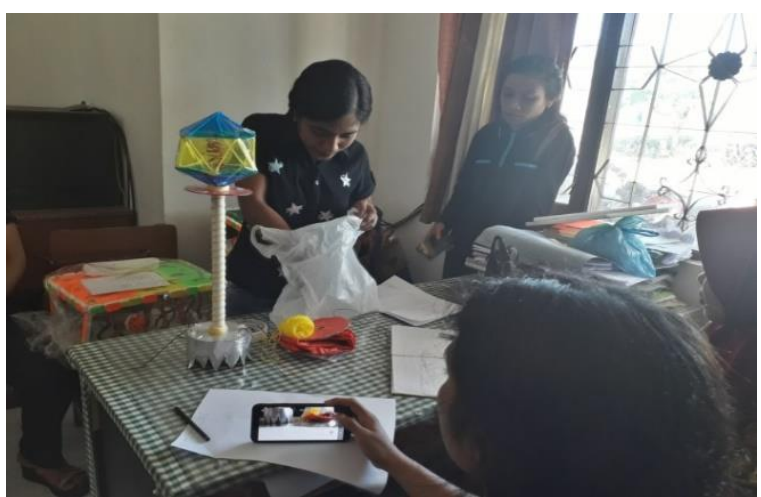

Gambar 4. Pembuatan Media 3 Dimensi virus Bakteriofag

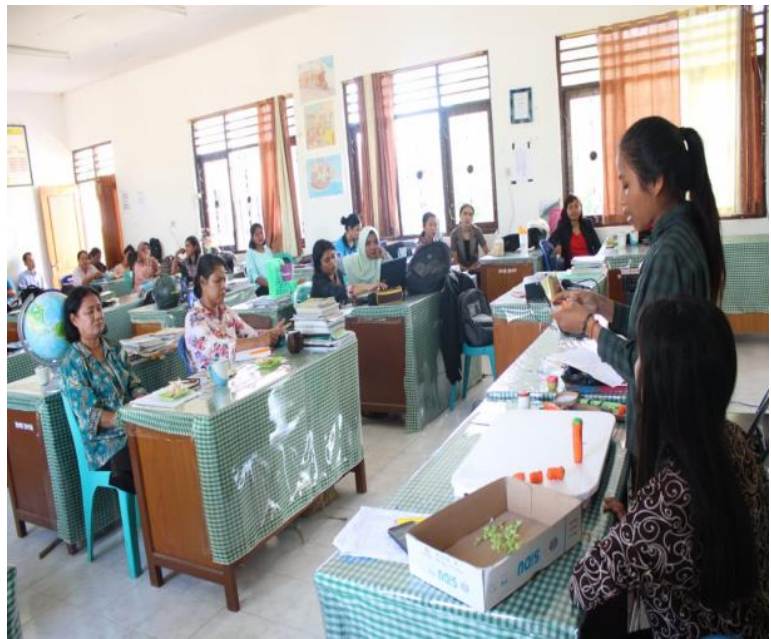

Gambar 5. Pembuatan Media 3 Dimensi Kultur Jaringan 


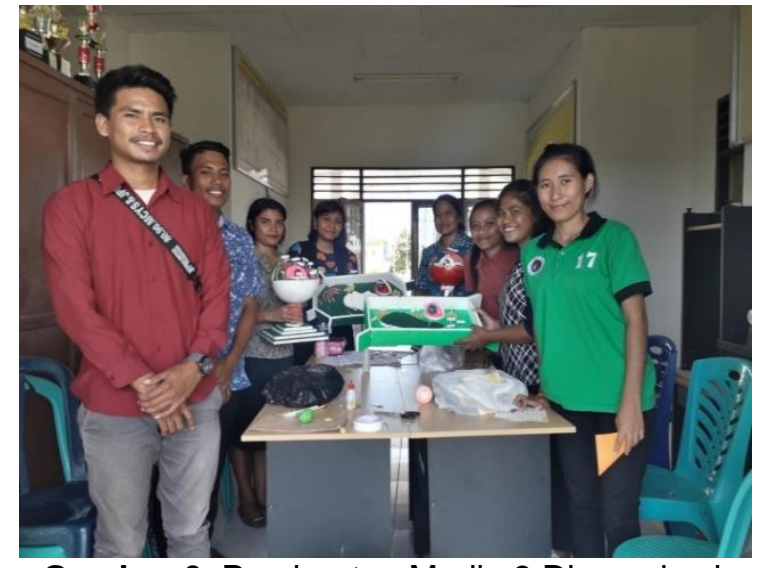

Gambar 6. Pembuatan Media 3 Dimensi sel hewan dan sel tumbuhan

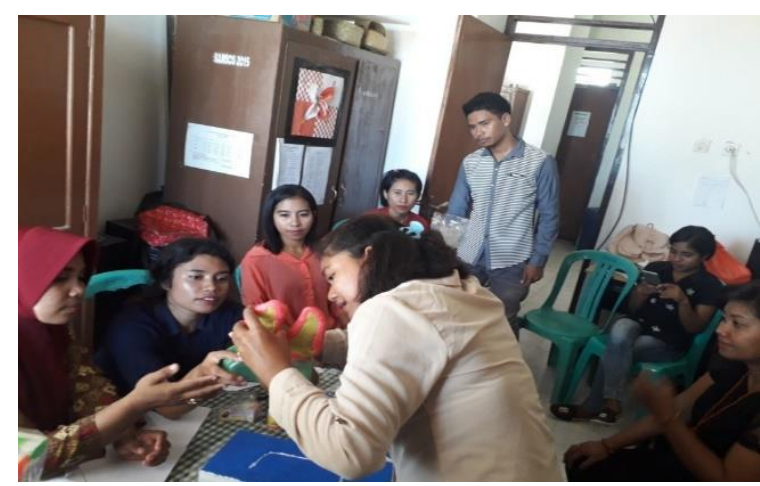

Gambar 7. Pembuatan Media 3 Dimensi

Sistem Pernapasan

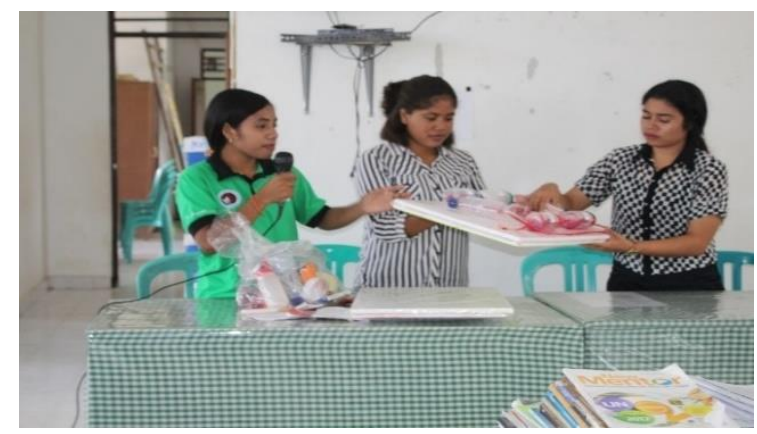

Gambar 8. Pembuatan Media 3 Dimensi Sistem Peredaran Darah

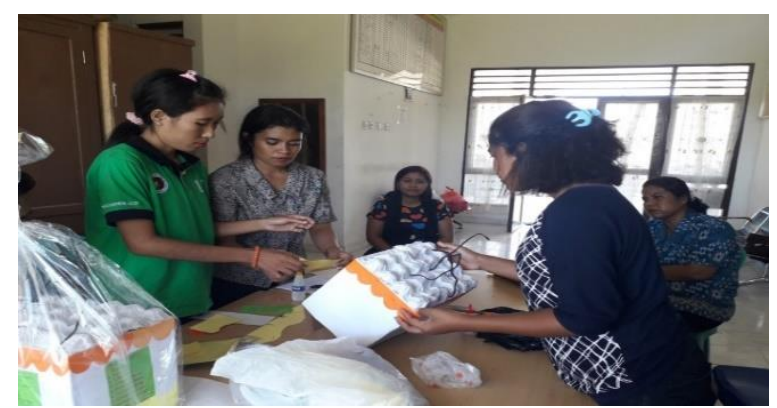

Gambar 9. Pembuatan Media 3 Sistem Ekskresi
Setelah kegiatan selesai dilaksanakan, para guru Biologi memberikan umpan balik terhadap proses pelaksanaan praktek simulasi pembuatan media pembelajaran. Guru Biologi menyatakan bahwa, kegiatan ini sangat bermanfaat bagi guru untuk menyiapkan, membuat dan menggunakan media pembelajaran dalam kelas. (Suryanda et al., 2020) menyatakan bahwa media pembelajaran merupakan bagian penting dalam proses pembelajaran. Guru Biologi harus mampu membuat dan mengembangakan media pembelajaran, karena tuntutan terhadap hasil belajar Biologi saat ini semakin meningkat.

Selain itu Kepala Sekolah SMA Negeri 1 Kambera juga menyatakan bahwa pihak sekolah merasa sangat puas dengan pengabdian masyarakat yang dilakukan oleh Prodi Pendidikan Biologi Unkriswina dalam bentuk simulasi pembuatan dan penggunaan media pembelajaran Biologi. Kepala sekolah juga meminta agar Prodi Kembali melaksanakan kegiatan tersebut di masa yang akan datang di sekolah tersebut.

\section{SIMPULAN DAN SARAN Simpulan}

Pelaksanaan simulasi pembuatan dan penggunaan media pembelajaran Biologi mampu meningkatkan antusias dan motivasi guru dalam memanfaatkan media pembelajaran.

\section{Saran}

Saran yang diberikan kepada pelaksana kegiatan adalah, agar kegiatan pelatihan ini dapat dilaksanakan lagi dengan jumlah peserta yang lebih banyak, misalnya pada skala Musyawarah Guru Mata Pelajaran (MGMP) Biologi di Kabupaten Sumba Timur.

\section{UCAPAN TERIMA KASIH}

Tim Pengabdian mengucapkan terima kasih kepada Universitas Kristen Wira Wacana Sumba yang telah membantu dalam hal dana pengabdian dan juga SMA Negeri 1 Kambera yang memberikan tempat dan kesempatan untuk dilakukan kegiatan ini.

\section{DAFTAR RUJUKAN}

Nurmadiah, N. (2016). Media Pendidikan. AlAfkar: Jurnal Keislaman \& Peradaban, 5(1). https://doi.org/10.28944/afkar.v5i1.109

Putri Purwaningrum, J., \& Ahyani, L. N. (2020). Pelatihan Pembuatan Dan Penggunaan Alat Peraga Matematika Pada Materi Luas Daerah Belah Ketupat Dengan Pendekatan Luas Daerah Segitiga. SELAPARANG Jurnal 
Pengabdian Masyarakat Berkemajuan, 4(1).

https://doi.org/10.31764/jpmb.v4i1.244 9

Soimah, I. (2018). Pengaruh Media Pembelajaran Berbasis Komputer Terhadap Hasil Belajar Ipa Ditinjau Dari Motivasi Belajar Siswa. Natural: Jurnal Ilmiah Pendidikan IPA, 5(1). https://doi.org/10.30738/natural.v5i1.2 559

Suryanda, A., Azrai, E. P., \& Setyorini, D. (2020). Media Pembelajaran Inovatif Berbasis Potensi Lokal untuk Meningkatan Kompetensi Profesional Guru IPA. Jurnal SOLMA,9(1). https://doi.org/10.29405/solma.v9i1.44 06

Tammu, R. M. (2018). Keterkaitan Metode dan Media Bervariasi dengan Minat Siswa dalam Pembelajaran Biologi Tingkat SMP. Jurnal Pendidikan (Teori Dan Praktik), 2(2). https://doi.org/10.26740/jp.v2n2.p134142 